\title{
Widening higher education participation in rural communities in England: An
}

\author{
anchor institution model
}

Geoffrey Elliott ${ }^{1}$

\begin{abstract}
Against a United Kingdom policy background of attempts to widen higher education participation in a socially inclusive direction, this article analyses theory, policy and practice to understand why past efforts have had limited success and to propose an alternative: an "anchor institution" model. A university and a private training provider were the principal partners in this venture, known as the South-West Partnership; the model was developed by them to meet the particular needs of mature female students who want and/or need to study part-time in a rural, coastal and isolated area of south-west England. While the concept of "anchor institutions" has previously been used in government social policy, and in higher education to promote knowledge transfer, it has not yet been adopted as a method for widening participation. The research study presented in this article investigated the effectiveness of the model in widening higher education participation in the context of the South-West Partnership. The study was conducted within an interpretivist theoretical framework. It accessed student voice to illustrate the character of education required to widen participation in vocational higher education by mature female students in rural communities, through semi-structured qualitative interviews on a range of topics identified from relevant theoretical literature, and by drawing on the research team's professional knowledge and experience. These topics included student aspirations and career destinations, motivations, access, learning experiences, and peer and tutor support. It is hoped the findings will inform the future development of adult vocational higher education provision in rural areas, where opportunities have been limited, and encourage further application of the anchor institution model for widening participation elsewhere.
\end{abstract}

Keywords higher education; widening participation; lifelong learning; access; rural; anchor institutions

Résumé Élargir la participation des communautés rurales anglaises à l'enseignement supérieur : le modèle d'institution d'ancrage - Sur fond d'une politique menée par le Royaume-Uni de Grande-Bretagne et d'Irlande du Nord visant à élargir la participation à l'enseignement supérieur dans un esprit d'inclusion sociale, cet article en analyse la théorie, les politiques et les pratiques afférentes, dans le but de cerner les raisons pour lesquelles les efforts déployés ont rencontré un succès limité, et de proposer une alternative : un modèle « d'institution d'ancrage ». Une université et un organisme privé de formation étaient les principaux partenaires de cette initiative connue sous le nom de Partenariat Sud-Ouest. Ils ont élaboré ce modèle pour répondre aux besoins spécifiques de femmes adultes souhaitant et/ou devant suivre des études à temps partiel dans une région rurale, côtière ou isolée du SudOuest de l'Angleterre. Si le concept « d'institution d'ancrage » a été auparavant utilisé dans des politiques sociales publiques ainsi que dans l'enseignement supérieur en vue de promouvoir le transfert des connaissances, il n'a pas encore été adopté en tant que méthode censée élargir la participation. L’étude de recherche présentée ici examine l'efficacité du modèle à élargir la participation à l'enseignement supérieur dans le contexte du Partenariat Sud-Ouest. Elle a été menée dans un cadre d'interprétation théorique. Elle fait entendre les opinions des étudiantes en vue d’illustrer le caractère requis de la formation pour élargir la 
participation à l'enseignement professionnel supérieur des femmes adultes dans les communautés rurales - ce à travers des interviews qualitatives semi-structurées sur une série de thèmes tirés de la littérature théorique afférente, ainsi que les connaissances et expériences professionnelles de l'équipe de recherche. Parmi ces thèmes figurent les aspirations, intentions et motivations des étudiantes, leur accès à la formation, leurs expériences d'apprentissage, enfin le soutien de la part des pairs et des tuteurs. L'auteur espère que les résultats de cette étude éclaireront le développement futur de l'enseignement professionnel supérieur des adultes dans les régions rurales caractérisées par des opportunités limitées, et encourageront l'extension du modèle de l'institution d'ancrage dans l'optique d'élargir la participation en d'autres lieux.

${ }^{1}$ Geoffrey Elliott $(\square)$

University of Worcester, Worcester, United Kingdom

e-mail: g.elliott@worc.ac.uk

\section{Introduction - the challenge of widening participation in higher education}

This article arose from my professional knowledge and experience of working for over 25 years in the area of lifelong learning, and my interest in widening access to and participation in higher education ${ }^{1}$ through educational partnerships. The focus in the supporting theoretical literature on a new model for extending higher education participation in rural and isolated areas is particularly pertinent since there is increasingly a broad consensus at government and policy level - in Europe in general (CoE 2017) and in the United Kingdom (UK) in particular - that such participation is a key indicator of a healthy society (BIS 2013), contributing significantly to economic development (Willetts 2014), revitalising business and industry (Wilson 2012), preparing a highly skilled workforce for the knowledge economy (BIS 2015a), and providing personal fulfilment as well as health benefits to individuals (BIS 2013). A number of countries have set higher education participation targets, including Sweden, Ireland, Australia and Germany; and this, alongside enhancing higher education system performance, remains a key policy objective of the Organisation for Economic Co-operation and Development (OECD 2017).

The most recently available government figures show that around 43 per cent of 17-30year-olds in the UK are now in some form of higher education (BIS 2015b). Many new opportunities in this area have been provided by further education colleges (FECs). Indeed, since 2011-2012 more full-time entrants to undergraduate courses other than first degrees have been studying in FECs rather than in higher education institutions (HEIs) (HEFCE

\footnotetext{
${ }^{1}$ Higher education refers to study undertaken after completion of secondary school.
} 
2014). Although many FECs offer courses in partnership with HEIs, they are increasingly seeking powers to award degrees in their own right (BIS 2016a).

However, access to higher education in the UK is not evenly distributed. Opportunities to study part-time have been severely reduced due to declining funding support (Hillman 2015). For example, in 2008-2009 the Labour Government introduced a policy to phase out funding for students in England who already hold a qualification at the same or higher level, and in 2012, requiring students to commit upfront to completing an entire degree in order to be eligible for a loan, removed the possibility of studying on a module-by-module basis. The impact was that between 2008 and 2012 the number of entrants to part-time higher education courses in England fell by 37 per cent (Oxford Economics 2014), and the number of part-time undergraduate students in 2013-2014 was half of what it had been in 2010-2011 (HEFCE 2014).

These demographic shifts have impacted sharply on social mobility and social justice (see, for example, Avis and Orr 2016). They particularly disadvantage women (such as those interviewed during this study) who have left school to obtain employment without entering higher education, and in many cases are also raising a family and thus need to continue working to meet living costs. Access to higher education is also restricted due to the uneven geographical spread of HEIs, particularly in rural and isolated areas (Gibney 2013). This is the case in the area of south-west England where this research was situated.

In England, responsibility for data provision and policy development on higher education access and participation is devolved by government to the Office for Fair Access (OFFA). OFFA has recently expressed concern over falling numbers of mature students ${ }^{2}$ in higher education, especially those who study part-time due to personal or work circumstances. It has also confirmed a significant variation in enrolment by region and geography, "which is important because part-time students are more likely than full-time students to study close to home” (HEFCE and OFFA 2014, p. 28). Indeed, young people in south-west England are the least likely to go to university (UCAS 2014).

There have been attempts made by some universities to close this access gap. These include e-learning (learning conducted using electronic media, such as the Internet) (Gorard and Selwyn 1999), and partnership arrangements loosely described as "hub and spoke”, where a HEI validates and sometimes helps to deliver courses in a number of "satellite" campuses or colleges $^{3}$ (Foskett 2002), as well as consortia where groups of colleges - sometimes with one or more university partners and/or other stakeholders - pool their resources to extend the

\footnotetext{
${ }^{2}$ In the UK, mature students are considered to be those aged 21 or over at the start of their studies.

3 "Satellite" campuses or colleges are branches of a larger institution, located in different areas.
} 
course offerings within their institutions (Dhillon 2005). Occasionally, higher education provision has also been developed and delivered in community centres and similar venues in rural areas. However, in many cases this has proved to be extremely challenging, expensive and unsustainable given the level of investment needed (IU 2015). Certainly, each of these models for widening access to higher education has to some extent also contributed to widening participation. However, no solution has yet been found to be wholly effective. In the case of HEI/FEC partnerships, there are many examples of HEIs having set up joint course arrangements with FECs only to withdraw when funding or policy demands have made such collaboration difficult (Scott 2010). There is thus no sense of an enduring legacy, nor a strong impetus to try a new approach.

\section{The research context}

The key partners described in this study are a university and a private provider of higher education. Both institutions are involved in a range of other educational partnerships designed to widen access to and participation in higher education. In a joint approach to developing provision in the south-west of England (known as the South-West Partnership), both agreed that a new model was needed to make sustainable and quality higher education more widely available. Their key goal was a model which met both local employment demand and was responsive to the personal needs of the predominantly mature female students. The core principle and method of the model is reflected in its name - the "anchor institution" model. Higher education is developed and offered by partners who have an identity, presence, reputation, knowledge and investment in the local area, and are reliable, secure and enduring: hence "anchor institutions". The initiative described in this article builds on the growing social phenomenon of anchor institutions, which relies on the idea that positive social and economic change in the context of increasingly fragile local economies and widening social disparities requires stable, enduring institutions such as colleges, universities, hospitals, community foundations, libraries and arts organisations "to harness their resources in order to address critical issues such as education, economic opportunity and health” (AITF 2016). This model is more fully discussed in the conclusion to this article.

The South-West Partnership was established in 2004 to deliver a range of SchoolCentred Initial Teacher Training (SCITT) programmes in a rural, coastal and isolated area of south-west England. At this time, the English educational policy direction was oriented towards giving greater responsibility for the content and delivery of teacher education courses 
to schools, while minimising the influence and involvement of university departments of education. In this context, the university developed a strategy for providing significant and growing collaborative higher education based upon partnerships to widen access to vocational higher education, ${ }^{4}$ mainly with satellite FECs located within 30 miles (almost 50 kilometres) of its city campus. Thus, developing a partnership with a private provider located more than 200 miles (just over 320 kilometres) away represented both a change and a challenge.

The private provider is a not-for-profit enterprise registered as a charity. It began as a community college that developed and taught franchised teacher education courses, and then expanded to develop, with its university partner, higher level vocational courses in education. The two institutions agreed on a shared focus upon

professionals in education, health, children's and young people's services who can benefit from a course leading to a higher education qualification, learners from underrepresented groups within higher education, learners from HE cold spots in the South West and capacity building internally and with target communities (internal discussion document).

The private provider operates with a small core of permanent staff who work mainly in managerial, administrative, coordination and support roles. Currently, over 50 teaching staff deliver courses in various locations in the region, with the majority employed on an hourly paid lecturer basis. All teaching staff must be accredited by the university and are subsequently designated as "associate staff”.

In 2009, the private provider proposed a wider lifelong learning agenda to the university that was responsive to identified local needs. The first option offered was a Foundation Degree (FD), and later, a Bachelor of Arts (BA) top-up degree was added which aimed at a growing local workforce of classroom assistants and education support staff. The FD award, the focus of the study presented here, was introduced in England in 2001 by the Department for Education, specifically to meet the needs of students wishing to combine academic and vocational higher education courses, with the curriculum often tailored to a single profession or occupational area. An FD is equivalent to two-thirds of an honours degree, and is often studied part-time to enable students to combine “earning and learning”. The school and professional networks created through the SCITT programme have been fundamental in making these new courses possible. For the university involved in the partnership, the proposed provision met its widening participation mission - a requirement for all publicly

\footnotetext{
${ }^{4}$ Vocational higher education refers to technical training related to specific occupations or trades; outcomes range from certificates to diplomas. It is also commonly referred to as further education (FE) or vocational education and training (VET).
} 
funded institutions in England- and represented a logical extension of its teacher education programmes into the wider education workforce.

\section{Theoretical positioning and context}

Both the current (BIS 2016b) and previous UK governments (DfES 2003, BIS 2011) have maintained a broad policy commitment to increase the number of mature students in higher education, through removing the cap on student numbers and ensuring that loans are available initially for undergraduate and now for postgraduate courses (DfE 2016). However, the barriers to older students entering higher education are many, including limited or no availability of on-site child care; scheduling of classes; competing demands of family, work and study; and financial pressures (McGivney 1999, Osborne et al. 2004, Marandet and Wainwright 2010, Brooks 2012). Perhaps more worryingly, as a recent UK Cabinet Officesponsored report found, higher education is often seen as the enemy of rural communities, because university is commonly understood to take young people away (IU 2016). Indeed, in preliminary reflections and conversations with South-West Partnership staff and other colleagues involved in local course delivery, it was anticipated that family, work and social networks would play a significant part in influencing decisions to enter higher education, especially where individuals were older, returning to learning, had experienced negative early educational experiences, or were balancing the competing priorities of family, work and study.

The students interviewed for this study were participating in higher education despite acceleration of a number of permeating and cross-cutting hindrances fuelled by the twin forces of neo-liberal dogma and austerity. ${ }^{5}$ The new higher education environment is characterised by notions of the rule of the market and individualism rather than community and the public good; deregulation and privatisation rather than state ownership and sponsorship; reduced public investment in education and social services; accounting and economic models of education rather than education as emancipation and social benefit; and fees and loans rather than grants. In this last respect, higher education course fees in England are amongst the highest in the developed world which highlights that this shift has been more extreme in England than in the rest of the UK and internationally.

\footnotetext{
${ }^{5}$ Neo-liberal dogma refers to a rigid form of liberal politics that favours free-market capitalism; austerity is a set of government measures designed to reduce public expenditure.
} 
Against this background, a number of studies utilising interpretivist, feminist or Bourdieusian perspectives ${ }^{6}$ have convincingly shown how important social and cultural influences are in shaping individual choices about whether or not to enter higher education (Allan et al. 2009, Crozier and Reay 2011). Furthermore, having negotiated entry into higher education, many non-traditional students find themselves socially and culturally misaligned with the mainstream university environment, to the extent that they fare badly or withdraw. As Andrew Wilkins and Penny Burke argue:

academic culture(s) - far from a neutral terrain, divested of cultural and class prejudice - is in reality disciplinary, hierarchical, authoritative and entrenched (to differing extents) in institutional and cultural bias (Wilkins and Burke 2015, p. 435).

Faced with such a misalignment, interventions and solutions have been largely sought through attempted cultural and structural changes within universities (Webber 2014), through partnership-based collaborative provision between universities and FECs (Elliott 2016), and through providing higher education in FECs (Kadi-Hanifi and Elliott 2016). ${ }^{7}$

The students in the study presented here largely conformed to the pattern found by Gareth Parry et al. when they looked at higher education students who were taught outside universities (though in their study these were FE-based students). They found that compared to those studying at universities, these students were "older, more likely to be studying parttime and, in the case of undergraduate entrants, more likely to have come from areas of low participation in higher education” (Parry et al. 2012, pp. 12-13). Likewise, the students interviewed in the current study were predominantly women employed in education support roles in schools, many of whom had raised a family and now had the opportunity to focus on their own study and career development. Data from 14 of these interviews (more details are provided below in the section on students) have been drawn on for discussion in this article.

Overall, there has been relatively little coverage in the international lifelong learning literature of the participation in higher education of those living in remote or rural areas, superficially because they are relatively few in number (Tight 2012, p. 212), but more importantly because the

\footnotetext{
${ }^{6}$ Interpretivist perspectives refer to the theoretical view that reality is socially constructed and therefore contingent upon place, culture and social relationships; Bourdieusian perspectives extend the Marxist concept of economic capital to explain social hierarchies and power relationships in terms of social, educational, cultural, financial and symbolic capital.

${ }^{7}$ The journal Research in Post-Compulsory Education published an entire special issue on higher education in further education (2016, Volume 21, Issue 1-2), entitled “Appraising and Reconfiguring HE in FE through Research and Critical Perspectives”.
} 
emphasis upon selection and opportunities for individuals through raising aspirations neither engages with the systematic disadvantage that certain communities experience nor with the ways that disadvantage may be reinforced by the approach universities may take in their work within those communities (Armstrong and Cairnduff 2012, p. 921).

It is therefore important to understand that proposed remedies must take into account both individual aspirations and motivations, as well as social justice factors that contribute strongly to the disparity in participation uncovered by academic research (Gray 2002) and policymakers (HEFCE 2015). In particular, many studies have demonstrated the constraints faced by women (Hinton-Smith 2016) and mature and part-time students (Murray and Klinger 2012); over 95 per cent of the participants in the study presented here ticked all three boxes. Thus, as well as managing the demands of family and work, these students were faced with thinly distributed higher education opportunities compared with their counterparts in more heavily populated urban settings. As Michele Fleming and Diana Grace note in an Australian context, "increasing participation in both education and employment requires a broader understanding of the social context in which this disparity has developed" (Fleming and Grace 2014, p. 483).

\section{Methodology}

The study presented here was part of a wider research project on university/college and university/private provider academic partnerships, involving seven academic tutors, professional support staff and myself as lead researcher. This phase of the project involved one-to-one hour-long interviews conducted by myself with 14 female students in the first or second year of their Foundation degree course in Teaching and Learning. The students were offered the opportunity to participate by their classroom tutor and advised that if they did not wish to do so there would be no disadvantage to them of any kind. All the students interviewed gave their full informed consent to participate and were advised that they were free to withdraw from the study at any point if they so wished. The interviews were semistructured, and followed themes identified through learning and teaching interactions with the students, professional knowledge and experience, and the theoretical literature relating to widening participation in higher education. The thematic areas thus explored during the interviews were wide-ranging and included: student aspirations, student motivation, resilience and perseverance, different ways of learning, professionality, time management, barriers to higher education access, access to and use of online resources, student learning experience, 
peer learning and online peer communities and tutor support. The interviews were recorded on a digital voice recorder, and videotaped, for later analysis.

\section{The Foundation Degree course}

Turning now to the partnership initiative described in this article, its inception (in 2009) was strategically focused on meeting local employment and skills needs through expanding higher education provision in the south-west of England. Local knowledge gained through existing collaboration with schools and sector bodies in the region pointed to the need for entry-level higher education in the form of FDs, initially in teaching and learning, and subsequently in health and care. As previously stated, the partnership between the university and the private provider of higher education had been established five years earlier (in 2004) to deliver the SCITT programme. It was this experience of school partnerships - essential for SCITT - that led to identifying a need for wider lifelong learning in the form of a professional vocational course for teaching assistants and other education support professionals.

The proposed course would need to be foundational and include elements of study skills, since the target group were predominantly women who held level 2/3 qualifications ${ }^{8}$ and who had left school several years previously. The university already had some experience in developing successful part-time FDs in education, health and other areas, and a review of options clearly showed that the FD was likely to be fit for purpose. The course was designed to require attendance at one of the local sites at times that suited participants and caused minimum disturbance to employers. The course team, comprising academic tutors from the University and the South-West Partnership, were clear, after their review of the theoretical literature and on the strength of their combined experience of teaching adult returners to study, that the course marketing, induction, design and teaching methods would need to be carefully tailored to the target population. In addition, the credibility of the partner institutions and their long-standing commitment to providing higher education in the community proved to be significant in underpinning the success of the initiative.

\section{The students}

\footnotetext{
${ }^{8}$ A "level 2" qualification is a secondary school leaving certificate also known as General Certificate of Secondary Education (GCSE; formerly Ordinary or O-level). It enables students who do not want to continue to A-levels to leave school and embark on an apprenticeship or join the workforce (with training) straight away.
} 
Having detailed the national policy and institutional background to this research study, I now turn to the students themselves. The study was designed to assess how effective the anchor institution model of higher education is for widening participation from the student perspective. First, in terms of student success within the South-West Partnership, the most recent set of data are shown in Table 1 . The completion rates - 83 per cent for the FD and 89 per cent for the BA - compare favourably with sector norms: for example, the average completion rate for students entering HEIs in England in 2009-2010 was projected to be 78.4 per cent (HEA 2012). Second, the course provision in the South-West Partnership consistently records very high student satisfaction scores in the National Student Survey, ${ }^{9}$ and student achievement compares favourably with the high scores in the majority of the partner university courses. Third, and in line with the focus of this article, we listened to the students as they reflected upon their experiences (during semi-structured interviews) of finding out about and entering higher education in a climate of low aspiration and in an area with few readily accessible universities, along with the transformative experiences that ensued.

Table 1 Performance of degree students in the South-West Partnership, 2015/2016

\begin{tabular}{|l|r|}
\hline Foundation Degree (FD) in Teaching and learning \\
\hline Number of students entering level 4 & 198 \\
\hline Number withdrawing through the year & 13 \\
\hline Number intercalating through year & 4 \\
\hline Number progressing to next year & 181 \\
\hline Number of students entering level 5 & 194 \\
\hline Number withdrawing through the year & 7 \\
\hline Number intercalating through year & 5 \\
\hline Number progressing to next year & 21 \\
\hline Number completing award & 161 \\
\hline Bachelor of Arts (BA) top-ups & 154 \\
\hline Number of students entering level 6 & 2 \\
\hline Number withdrawing through the year & 5 \\
\hline Number intercalating through year & 10 \\
\hline Number progressing to next year & 137 \\
\hline Number completing award & 28 \\
\hline Number gaining first-class honours & 55 \\
\hline $\begin{array}{l}\text { Number gaining 2:1 } \\
\text { (upper second-class honours) }\end{array}$ & 44 \\
\hline $\begin{array}{l}\text { Number gaining 2:2 } \\
\text { (lower second-class honours) }\end{array}$ & 9 \\
\hline $\begin{array}{l}\text { Number gaining 3 } \\
\text { (third-class honours) }\end{array}$ &
\end{tabular}

\footnotetext{
${ }^{9}$ The National Student Survey (NSS) is conducted annually by the Higher Education Funding Council for England (HEFCE) to examine students' opinions on the quality of their courses. For more information (and current figures), see http://www.hefce.ac.uk/lt/nss/results/ [accessed 21 November 2017].
} 
From the outset, local knowledge within the partnership discerned a higher education need amongst mature women living in the area who wanted to return to study after working and often raising a family, and who would need to study part-time. Coastal and rural areas such as this one were identified by government as being in particular need of improved higher education access (HEFCE 2013).

The following analysis and discussion of the position of the students in the study borrows from Karl Marx (1981 [1894]) and Pierre Bourdieu (1986) the idea of human and social capital (or knowledge); in particular, how these forms of capital are the basis of social life and influence human participation and position within society. The influence of capital can be seen in our study not only in relation to participation in higher education, but also crucially in the students' awareness and understanding of higher education itself - its existence in their rural community, its opportunities and relationship to employment prospects, and its potential for changing their lives. The permeating influence of capital is best understood by borrowing one of Bourdieu's (1992) sporting metaphors: many of those participating in our study lacked a "feel for the game". For example, while those with a privileged background and upbringing are more likely to "just know” how to successfully navigate university application processes and opportunities, many of our students lacked this form of capital. There are strong procedural benefits to adopting such a research focus. As has been noted in an international context, "the implementation level of access routes is influenced directly by institutional practice (on the supply side) and by the behaviour of prospective students (on the demand side)" (Orr and Hovdhaugen 2014, p. 47).

In the current study, the students were asked whether university was an option for them either when they were at school or when they left school. The responses were revealing (all names have been changed to protect anonymity).

Nicole To be honest, it was always, in the nicest possible way, posh people whose children went to university. None of my family have ever been, though my son's at [Name] University now, but none of us had ever ... It just didn't feel like an option, to be honest. I didn’t really hear anything about it, I didn’t know enough about it.

Stephanie No, I didn't [think about university when I left school]. I just wanted to leave school, I hated it. [Laughter.] To be fair, I just didn't really particularly have the most enjoyable experience of school. For me, I just, sort of, needed that break, and I think that, sort of, worked well for me.

Sophie I'd done my level three [certificate], ${ }^{10}$ but I didn't know about it. I didn't really know about, like, carrying on doing level four or anything. I'd just done my level

\footnotetext{
10 The British "level 3" secondary school leaving certificate, also known as General Certificate of Education (GCE) Advanced Level (A-level), qualifies school leavers to enter higher education, ”Level 4”
} 
three and then went to work. I didn’t really ... Well, I could have found out, but I didn't.

Cultural capital relates to having a "feel for the game" in all relevant spheres, not only those linked to upward social mobility. When Stephanie says that leaving school "worked well” for her, she relates her reality that the move from school to work and a weekly wage was a positive step, and that committing to the additional two years of schooling needed to gain the qualification to go on to university would not have worked for her. She also stated in her interview: "I wouldn’t have been able to fit it around my life.” On the other hand, for Sophie, school provided vocational capital in the form of a level 3 qualification that enabled her to gain a semi-skilled job. For both women, the institutionalised capital represented by a university education was far removed from what they knew they needed and wanted at the time. It is worth further investigation that in this community the perception that university “didn't feel like an option” is linked to suspicion about the notion of upward mobility, together with the idea that for these women status and power resides outside the prevailing middle-class norms.

There is a strong theme in the interview data that the students had internalised the habits and dispositions associated with immediate and familiar aspiration and achievement, and excluded higher education and its concomitant increased employment opportunities. To that extent, the students had self-censored the idea of a university education, quite apart from the practical difficulty of the limited number of higher education institutions and opportunities available in the community in which they lived and worked.

Elizabeth Like I said, it was my confidence. I didn't think I could do it. I felt stupid, that's the word. Yes, I just felt I didn't understand why I didn't understand things, so I just didn't want to get embarrassed and be up against people that just knew everything, and I couldn't keep up with them, and that would make me feel, yes, not very confident, so it's not really a good thing, when I don't know what everyone else is talking about in the room.

The golden thread running through the South-West Partnership's planning of all new higher education provision was that in order to meet the needs of potential students and the local economy, courses should be locally based and accessible to women who worked part-time and were raising a family. These elements were apparent in the following extracts taken from interviews with current students - many of whom were mothers with school-aged children, therefore course attendance needed to be close to home and work. 
Amanda I just couldn't believe the fate situation of it being on my doorstep. I'm literally two miles away, so it's perfect.

Sarah I'm a single parent. So, going to university was out of reach for me, so this was a perfect way of doing what I wanted to do and still being able to keep up with, hopefully, everything else ... and I've got very little support round here to look after my son. He's only eight, so I wouldn't have been able to do it.

Melissa I started working as a TA [teaching assistant] about three years before I started, and worked with a really inspirational teacher. She made me want to teach. I didn't really know how to do it, because I’ve got three children, a husband, a job, mortgage. I couldn't leave home to go to university like I would have when I was younger. I saw an advert in the paper for this particular degree, and it just sounded perfect, a way to achieve a degree without having to move away. I could still carry on working in my job, and it was on my doorstep, so yes.

Given the tremendous personal investment made by these students, it is clear that the FD appears to have high instrumentality, enabling them to bolster their self-esteem in the workplace, in terms of earning the qualification itself (where formerly there was none for associate professionals), and through work-based learning, the acquisition of specialist knowledge and its associated terminology that allows them to engage with colleagues in meaningful professional discourse. These themes are readily identified in the following extracts in which the students explained lucidly why they chose to study the FD in Teaching and Learning.

Ashley Because it’s a work-based project, isn’t it, so it means I can still ... I wouldn’t have gone to university to do it, because obviously, I need to have a job, I need to work to be able to, like, pay my rent and stuff, so it was a really good ... My friend showed me it, and I thought it was really good for me to further my career and also still be able to work and not have to worry about paying my rent or anything.

Nicole I'm in a teaching assistant role, and wanting to do something to, kind of, be qualified, because I think it just looks better for you, and it gives you a bit more in-depth ...

Elizabeth Well, I accepted the job of manager at the pre-school where I worked, and I just wasn't a very confident person, so I thought maybe by doing my degree, hopefully that would support me with, like, speaking to professionals and doing reports. Yes, just making me a better person, just supporting me with ... I'm not very good at, like ... I've just been diagnosed now with ... I'm dyspraxic and dyslexic, so I feel now I realise why I haven't been very confident, and why I struggle to do things. That's why I thought I would do this, and hopefully it will just make me be able to deal with situations at work that I find hard, understanding words. Yes, so it's really hard, so I'm hoping, through doing my degree, that it will make me be a bit more ... Not intelligent, but, you know, just understand that sort of language you need to use when you're working with other professionals. 
Just as important as the course's flexible design and relevance to the students' work situations is the student experience itself. Collaborative provision is often regarded as high risk in terms of quality and comparability with “mainstream” higher education (Craft 2010). Since 2005, all English HEIs have been required to evaluate final year undergraduates' opinions of the quality of their courses using the National Student Survey (HEFCE 2017). Whilst the current study did not seek specifically to test the student experience, the principal metric available the National Student Survey - confirms that the FD in Teaching and Learning is in the top decile of highly rated courses at the partner university. All the students interviewed were highly appreciative of the course experience, and highlighted both peer and tutor support as critical factors in enabling their academic progress.

Melissa A bit overwhelming, you know, it's a real learning curve. Each assignment that comes along is a bit ... You start it thinking, "How am I even going to do this?”. But every time you achieve it, you feel really good, so they've been really supportive. The group's amazing, that's been, probably, the biggest plus point is, like, the other students, and getting to know them.

Ashley Like, they [the tutors] don't make you feel like if you didn't know something, they don't make you feel, like, stupid. Always, I can approach any of them as well. They feel all really approachable and, for me, they teach really well. I like their style.

Sarah What I love most about each tutor that we've had is the enthusiasm they have for their subject, and it comes across when they're teaching, and they've really got a passion for it. They all seem to want us to do well.

Stephanie I like the fact that we're supported all the time. Literally, we've got support an email away ... I've got a really good bond with the other students, and we've, sort of, formed our own links that we can communicate outside of the university, through, sort of, social media and that sort of thing. Yes, I'm finding it really interesting. I'm really enjoying it.

There is now a substantial body of international theoretical literature that recognises the critical importance of peer and tutor support in bolstering student confidence and enhancing stamina (Boud et al. 2001, Llamas and Ramos-Sanchez 2013, De Backer et al. 2015, Busher et al. 2015). Given the multitude of potential barriers to entering and succeeding in higher education, it seems clear that strategies and initiatives designed to widen participation should address this dimension of the student experience, and put systems and opportunities in place that enhance peer and tutor support. This could include thorough and careful human resource management and professional development processes to ensure that appointed tutors understand the needs and frailties as well as the considerable strengths of adult students, and put strategies in place to support them. In addition, course design should embrace work- 
friendly patterns of attendance, which could be "day release” 11 with employer support, or scheduling classes outside of working hours. Finally, blended learning can combine attendance with online or distance learning, though care is needed to respect the evident need of adult students to learn together in a physical community of practice, along with addressing issues of computer literacy (Lea and Jones 2011), and information and communication technologies more broadly (Tummons et al. 2015).

\section{An “anchor institution” model for widening participation}

There have been a number of attempts to overcome the problem of increasing access to and participation in higher education in rural and isolated areas in England. Many if not all of these have been well-intentioned and have embraced the features of student support and course design outlined above. Unfortunately, most of these initiatives have been short-lived. Clearly, sustainability has become a critical factor in widening participation in higher education; as a result, educational understanding needs to be combined with sound business planning. In the context of this study, experienced, dedicated, flexible and locally based staff committed to lifelong learning was fundamental to the "anchor institution" concept and its sustainability.

Our analysis of the interview data resulted in identification of some core elements of an anchor institution model needed to effectively widen participation in higher education, which are now briefly summarised to show how central student perspectives are to the model. The "anchor institution” approach rests on an understanding of widening participation as pedagogy rather than process (McLellan et al. 2016). This includes the design of teaching, course structures and support mechanisms to accommodate students' needs and dispositions. This translated into a teaching and learning setting in which, as stated by Elizabeth, she did not feel "stupid" or put into a learning environment in which she felt "up against people that just know everything”. In addition, Melissa felt that tutors had been “really supportive”, and that learning which was peer supported and conducted in group settings facilitated, in Sophie’s words, “a really good bond with the other students”. Participants agreed that education provision should be centred on and in the community, relevant to work needs and aspirations, local but professionally focused, and delivered in a way that allows balance with work and family responsibilities. The learning should, in the words of Ashley, be "work-

\footnotetext{
${ }^{11}$ Day release means that employers "release” their employees, usually for one day per week, to attend off-site training.
} 
based" and enable her to earn while she learns, to "further my career and also still be able to work".

The private provider was viewed locally as part of the community and an enduring and trusted education provider. The partnership with the university was designed to add scale, status and credibility, with the students registered, taught and supported by university staff, and with opportunities to visit and access the university's resources and facilities, and to participate in regular graduation ceremonies conducted in the city cathedral. Both institutions in the partnership claim to be value-driven. The university was established as a college of education after the Second World War to "win the peace" through teacher education and training programmes. The private provider, operating since 2003, aims to embody the vision and values of its founder, an inspirational leader committed to improving professional education and development, who created an institution imbued with values of equality, opportunity, personal renewal, social transformation and economic regeneration. Both partners have a shared sense of and commitment to the values of inclusion and social justice, and wished to develop these as core to the academic offer, and to use their combined capital to positively transform the communities in which they operate.

In the UK, the government has advanced the concept of anchor institutions as part of a “building stronger communities and businesses” policy strand (Smallbone et al. 2015). The potential for anchor institutions to realise progressive change has meanwhile entered English higher education discourse predominantly linked to "third stream activity"12 (Allan 2016). However, its application to widening participation in higher education in any context - urban or rural - has yet to be addressed in international theoretical literature, where its present lack is surprising given the broadly accepted position that

we cannot understand the significance of current conceptions of knowledge and learning, or current practices of work-related education and training unless we are able to uncover and critically analyse the social relations that underpin these conceptions and practices (Mojab 2009).

This understanding is pivotal, since it points to the need for core institutions to utilise power, influence, resources and intent to support and bolster social movements which desire change and reform.

The sustainability of the South-West Partnership lies in integrating the "anchors" that have created an embedded movement out of a good idea, rather than a weakly supported

\footnotetext{
${ }^{12}$ Third stream activity refers to universities linking with business and other external organisations to promote knowledge exchange.
} 
initiative expected to succeed as a stand-alone intervention, thus avoiding the impoverished conceptualisation of sustainability which has limited our understanding of previous educational projects, as John Holford (2016) has already convincingly argued in this journal. Regretfully, this has been a weakness of many otherwise worthy widening participation projects, both small- and large-scale (Gale 2015; Harrison et al. 2015).

It is important, however, to note that alongside its enduring legacy, the model of anchor institutions has flexibility at its core. The provision of vocational higher education in the South-West Partnership is spread across a number of centres: mainly schools, but also a commercial business unit. Thus, it is not a static institution permanently in one place that is at the heart of the concept, for this would recreate the mistakes of the past: self-serving institutions that drain resources to feed themselves. Rather, anchor institutions have the potential to create a lasting impact in the communities in which they work, an impact which might or might not involve their own continuing physical presence.

The researchers involved in this study deliberated on whether "anchor" was the right metaphor for this model; however, since anchors can be both "lowered" and "raised" whilst serving their purpose in each location, we decided it was appropriate. In rural settings, therefore, it follows that any withdrawal of provision from one place should be accompanied by a thoroughly considered exit strategy which both meets the needs of continuing students and leaves an opportunity for re-entry as demand requires. As noted above, this requires careful business planning alongside educational judgement. Wherever possible, in this situation new partners should be sought, especially from within active communities, who can continue to develop educational opportunities.

This study is not blind to the view that the UK government's admiration for the "big society” idea (Gov UK 2011), of which anchor institutions are a part, owes its origins to fallout from the national economic crisis triggered by the collapse of the UK banking system in 2007-2008 (HoC 2009), and the recession and austerity politics that followed. More recently, this has been translated by the majority Conservative Government into a devolution agenda, "transferring power so people can make more decisions locally and solve their own problems to create strong, attractive and thriving neighbourhoods” (Cabinet Office 2017). Nor is this study insensitive to the view that the adverse global economic environment for education has permeated our thinking, planning and everyday language, in a "form of 'discourse capture' where radically different conceptual agendas such as those of education are re-interpreted through its language and values” (Bottery 2001, p. 204). 
However, sometimes locally based progressive educational and social movements can lead national policies, and successful and sustainable approaches which influence communities and create a new and positive direction for them could in time attract government support, and the resources to enable like-minded institutions to create further enduring widening participation opportunities elsewhere. This idea embodies a value orientation rather than, or more accurately as well as, a business orientation. But this can only happen if the major players in the educational landscape use their significant capital to support promising initiatives. Not doing so may undermine promising and innovative lifelong learning initiatives due to lack of anchorage of ideological support, resources and political action. Furthermore, the students themselves can tell us exactly how to progress and persevere if we listen more closely to them.

\section{References}

Allan, E., Iverson, S., \& Ropers-Huilman, R. (Eds) (2009). Reconstructing policy in higher education: Feminist poststructural perspectives. London: Routledge.

Allan, T. (2016). Universities as anchor institutions [online blogpost]. Bristol: Higher Education Funding Council for England (HEFCE). Retrieved 6 October 2016 from http://blog.hefce.ac.uk/2015/03/16/universities-as-anchor-institutions/.

AITF (Anchor Institutions Task Force) (2016). Anchor Institutions Task Force Literature review. New York, NY: AITF Marga [online resource]. Retrieved 3 February 2016 from https://www.margain.com/initiatives/aitf

Armstrong, D., \& Cairnduff, A. (2012). Inclusion in higher education: Issues in universityschool partnership. International Journal of Inclusive Education, 16(9), 917-928.

Avis, J., \& Orr, K (2016). HE in FE: Vocationalism, class and social justice. Research in Post-Compulsory Education, 21(1-2), 49-65.

BIS (Department for Business Innovation and Skills) (2011). Higher education: Students at the heart of the system. Cm 8122. Norwich: The Stationery Office (TSO). Retrieved 24 October 2017 from http://www.educationengland.org.uk/documents/pdfs/2011-whitepaper-higher-ed.pdf.

BIS (2013). The benefits of higher education participation for individuals and society. BIS Research Paper No. 146. London: Department for Business Innovation and Skills. Retrieved 24 October 2017 from https://www.gov.uk/government/uploads/system/uploads/attachment_data/file/254101/b is-13-1268-benefits-of-higher-education-participation-the-quadrants.pdf.

BIS (2015a). On target for a higher skilled workforce. Press release [online]. Retrieved 17 October 2016 from https://www.gov.uk/government/news/on-target-for-a-higherskilled-workforce.

BIS (2015b). Participation rates in higher education: Academic years 2006/2007-2013/2014 (provisional) [online resource]. Retrieved 16 October 2016 from https://www.gov.uk/government/uploads/system/uploads/attachment_data/file/458034/ HEIPR_PUBLICATION_2013-14.pdf. 
BIS (2016a). Success as a knowledge economy: Teaching excellence, social mobility \& student choice. White paper. Cm 9258. London: Department for Business, Innovation and Skills (BIS). Retrieved 24 October 2016 from https://www.gov.uk/government/publications/higher-education-success-as-aknowledge-economy-white-paper.

BIS (2016b). Higher education and research Bill [online resource]. Retrieved 16 October 2016 from http://services.parliament.uk/bills/2016-17/highereducationandresearch.html.

Bottery, M. (2001). Globalisation and the UK competition state: No room for transformational leadership in education? School Leadership and Management, 21(2), 199-218.

Boud, D., Cohen, R., \& Sampson, J. (2001). Peer learning in higher education: Learning from and with each other. London: Kogan Page.

Bourdieu P. (1986). The forms of capital. In J. Richardson (Ed.), Handbook of theory and research for the sociology of education (pp. 241-58). New York: Greenwood.

Bourdieu, P. (1992). An invitation to reflexive sociology. Cambridge: Polity Press.

Brooks, R. (2012). Student-parents and higher education: A cross-national comparison. Journal of Education Policy, 27(3), 423-439.

Busher, H., James, N., \& Piela, A. (2015). "I always wanted to do second chance learning”: Identities and experiences of tutors on Access to Higher Education courses. Research in Post-Compulsory Education, 20(2), 127-139.

Cabinet Office (2017). Policy area: Community and society [online resource]. Retrieved 11 May 2017 from https://www.gov.uk/government/topics/community-and-society.

CoE (Council of Europe) (2017). Higher education and research statement [Online]. Retrieved 16 May 2017 from http://www.coe.int/t/dg4/highereducation/CompletedActivities/Access_EN.asp.

Craft, A. (2010). The assessment of quality risks in collaborative provision. Quality Assurance in Education, 10(1), 25-29.

Crozier, G., \& Reay, D. (2011). Capital accumulation: Working class students learning how to learn in higher education. Teaching in Higher Education, 16(2), 145-155.

De Backer, L., Van Keer , H., \& Valcke, M. (2015). Promoting university students' metacognitive regulation through peer learning: The potential of reciprocal peer tutoring. Higher Education, 70(3), 469-486.

DfE (Department for Education) (2016). Postgraduate loans [online resource]. Retrieved 16 October 2016 from https://www.gov.uk/postgraduate-loan/overview.

DfES (Department for Education and Skills) (2003). The future of higher education. Cm 5735. Norwich: The Stationery Office (TSO). Retrieved 24 October 2017 from http://www.educationengland.org.uk/documents/pdfs/2003-white-paper-higher-ed.pdf.

Dhillon, J. (2005). The rhetoric and reality of partnership working. Journal of Further and Higher Education, 29(3), 211-219.

Elliott, G. (2016). Challenging assumptions about values, interests and power in further and higher education partnerships. Journal of Further and Higher Education, 41(2), 143154.

Fleming, M., \& Grace, D. (2014). Increasing participation of rural and regional students in higher education. Journal of Higher Education Policy and Management, 36(5), 483495.

Foskett, N. (2002) Marketing imperative or cultural challenge: Embedding widening participation in the further education sector. Research in Post-Compulsory Education, 7(1), 75-95.

Gale, T. (2015). Widening and expanding participation in Australian higher education: In the absence of sociological imagination. The Australian Educational Researcher, 42(2), 257-271. 
Gibney, E. (2013). Concentration of UK universities v population distribution. Times Higher Education, 8 August [online article]. Retrieved 16 October 2016 from https://www.timeshighereducation.com/news/concentration-of-uk-universities-vpopulation-distribution/2006284.article.

Gorard, S., \& Selwyn, N. (1999). Switching on the learning society? - Questioning the role of technology in widening participation in lifelong learning. Journal of Education Policy, 14(5), 523-534.

Gov UK (Government of the United Kingdom of Great Britain and Northern Ireland) (2011). Building the big society. Conservative-Liberal Democrat Government statement [online resource]. Retrieved 17 October 2016 from

https://www.gov.uk/government/uploads/system/uploads/attachment_data/file/78979/bu ilding-big-society 0 .pdf.

Gray, F. (2002). Landscapes of learning: Lifelong learning in rural communities. Leicester: National Institute of Adult and Continuing Education (NIACE).

Harrison, N., Waller, R., \& Last, K. (2015). The evaluation of widening participation activities in higher education: A survey of institutional leaders in England. Assessing Impact and Measuring Success (AIMS) project Working Paper 1: June 2015 Bristol: University of the West of England (UWE). Retrieved 12 May 2017 from http://www2.uwe.ac.uk/faculties/CAHE/Documents/Research/BRILLE/Report\%201\%2 0-\%20Institutional\%20Survey\%20-\%20June\%202015.pdf.

HEA (Higher Education Academy) (2012). Building student engagement and belonging in higher education at a time of change. Final report from the What Works? Student Retention and Success programme. London: Paul Hamlyn Foundation. Retrieved 2 November 2016 from https://www.heacademy.ac.uk/system/files/what_works_final_report.pdf.

HEFCE (Higher Education Funding Council for England) (2013). Trends in young participation in higher Education. Bristol: HEFCE. Retrieved 24 October 2017 from http://www.hefce.ac.uk/media/hefce/content/pubs/2013/201328/HEFCE_2013_28.pdf.

HEFCE (2014). Higher education in England 2014: Analysis of latest shifts and trends. Bristol: HEFCE. Retrieved 11 May 2017 from http://www.hefce.ac.uk/analysis/HEinEngland/HEENG/heeng14/.

HEFCE (2015). Student mobility [online resource]. Retrieved 6 October 2016 from http://www.hefce.ac.uk/analysis/maps/student/.

HEFCE (2017). National student survey [online resource]. Retrieved 12 May 2017 from http://www.hefce.ac.uk/lt/nss/.

HEFCE \& OFFA (Higher Education Funding Council for England and the Office for Fair Access) (2014). National strategy for access and student success in higher education. BIS/14/516. London: London: Department for Business, Innovation and Skills (BIS). Retrieved 24 October 2017 from https://www.gov.uk/government/uploads/system/uploads/attachment_data/file/299689/b is-14-516-national-strategy-for-access-and-student-success.pdf.

Hillman, N. (Ed.) (2015). It's the finance, stupid! The decline of part-time higher education and what to do about it. Oxford: (Higher Education Policy Institute (HEPI). Retrieved 17 October 2016 from http://www.hepi.ac.uk/wp-content/uploads/2015/10/parttime_web.pdf.

Hinton-Smith, T. (2016). Negotiating the risk of debt-financed higher education: The experience of lone parent students. British Educational Research Journal, 42(2) 207222.

HoC (House of Commons) (2009). Banking crisis: Dealing with the failure of the UK banks. HC 416. London: House of Commons: Treasury Committee Retrieved 16 October 2016 
from

https://www.publications.parliament.uk/pa/cm200809/cmselect/cmtreasy/416/416.pdf.

Holford, J. (2016). The misuses of sustainability: Adult education, citizenship and the dead hand of neoliberalism. International Review of Education, 62(5), 541-561.

IU (IntoUniversity) (2016). Rural aspiration: Access to higher education in rural, coastal and dispersed communities. London: IntoUniversity. Retrieved 5 October 2016 from http://intouniversity.org/sites/all/files/userfiles/files/IntoUniversity\%20Rural\%20Aspira tion\%20Report\%202015.pdf.

Kadi-Hanifi, K., \& Elliott, G. (2016). Appraising and reconfiguring HE in FE through research and critical perspective. Editorial to a special issue on Higher Education in Further Education. Research in Post-Compulsory Education, 21(1-2), 1-8.

Lea, M., \& Jones, S. (2011). Digital literacies in higher education: Exploring textual and technological practice. Studies in Higher Education, 36(4), 377-393.

Llamos, J., \& Ramos-Sanchez, L. (2013). Role of peer support on intragroup marginalization for Latino undergraduates. Journal of Multicultural Counseling and Development, 41(3), 158-168.

McGivney, V. (1999). Returning women: Their training and employment choices and needs. Leicester: National Institute of Adult and Continuing Education (NIACE).

McLellan, J., Pettigrew, R., \& Sperlinger, T. (2016). Remaking the elite university: An experiment in widening participation in the UK. Power and Education, 8(1), 54-72.

Marandet, E., \& Wainwright, E. (2010). Invisible experiences: Understanding the choices and needs of university students with dependent children. British Educational Research Journal, 36(5), 787-805.

Marx, K. (1981 [1894]). Capital: A critique of political economy. Vol. 3. Harmondsworth: Penguin.

Mojab, S. (2009). Turning work and lifelong learning inside out: A Marxist-feminist attempt. In L. Cooper and S. Walters (Eds), Learning/work: Turning work and lifelong learning inside out (pp. 4-15). Cape Town: HSRC Press.

Murray, N., \& Klinger, C. (2012). Dimensions of conflict: Reflections on the higher education experience from an access education perspective. International Journal of Lifelong Education, 31(2), 117-133.

OECD (Organisation for Economic Cooperation and Development) (2017). Enhancing higher education system performance: Why we are doing this work now [webpage]. Retrieved 14 May 2017 from http://www.oecd.org/edu/skills-beyond-school/enhancing-highereducation-system-performance-why-we-are-doing-this-work-now.htm.

Orr, D., \& Hovdhaugen, E. (2014). “Second chance” routes into higher education: Sweden, Norway and Germany compared. International Journal of Lifelong Education; 33(1), 45-61.

Osborne, M., Marks, A., \& Turner, E. (2004). Becoming a mature student: How adult applicants weigh the advantages and disadvantages of higher education. Higher Education, 48(3), 291-315.

Oxford Economics (2014). Macroeconomic influences on the demand for part-time higher education in the UK. Report to HEFCE. Oxford: Oxford Economics. Retrieved 20 October 2014 from www.oxfordeconomics.com/publication/open/249712.

Parry, G., Callender, C., Scott, P., \& Temple, P. (2012). Understanding higher education in further education colleges. BIS Research Paper Number 69. London: Department for Business, Innovation and Skills (BIS). Retrieved 24 October 2017 from http://dera.ioe.ac.uk/14785/1/12-905-understanding-higher-education-in-furthereducation-colleges.

Scott, G. (2010). Delivering higher education within further education in England: Issues, tensions and opportunities. Management in Education, 24(3), 98-101. 
Smallbone, D., Kitching, J., Blackburn, R., \& Mosavi, S. (2015). Anchor institutions and small firms in the UK: A review of the literature on anchor institutions and their role in developing management and leadership skills in small firms. Wath-upon-Dearne: UK Commission for Employment and Skills (UKCES). Retrieved 6 October 2016 from https://www.gov.uk/government/uploads/system/uploads/attachment_data/file/414390/ Anchor_institutions_and_small_firms.pdf.

Tight, M. (2012). Widening participation: A post-war scorecard. British Journal of Educational Studies, 60(3), 211-226.

Tummons, J., Fournier, C., Kits, O., \& MacLeod, A. (2015). Teaching without a blackboard and chalk: Conflicting attitudes towards using ICTs in higher education teaching and learning. Higher education Research and Development, 35(4), 829-840.

UCAS (Universities and Colleges Admissions Service) (2014). End of cycle report 2014. Cheltenham: UCAS.

Webber, L. (2014). Accessing HE for non-traditional students: “Outside of my position”. Research in Post-Compulsory Education, 19(1), 91-106.

Wilkins, W., \& Burke, P. (2015). Widening participation in higher education: The role of professional and social class identities and commitments. British Journal of Sociology of Education, 36(3), 434-445.

Willetts, D. (2014). Contribution of UK universities to national and local economic growth. Speech delivered by Universities and Science Minister David Willetts on 3 April to the Universities UK (UUK) conference. London: Department for Business, Innovation and Skills (BIS). Retrieved 17 October 2016 from https://www.gov.uk/government/speeches/contribution-of-uk-universities-to-nationaland-local-economic-growth.

Wilson, T. (2012). A review of business-university collaboration. London: Department for Business, Innovation and Skills (BIS). Retrieved 17 October 2016 from https://www.gov.uk/government/uploads/system/uploads/attachment_data/file/32383/12 -610-wilson-review-business-university-collaboration.pdf.

\section{The author}

Geoffrey Elliott has taught in comprehensive schools, and in further, adult and higher education, and has undertaken a range of leadership roles during his career. He is President of the UK Association for Research in Post-Compulsory Education, and serves on the Board of the UK Office of the Independent Adjudicator for Higher Education. He edits the international peer-reviewed journal Research in Post-Compulsory Education, and is currently Professor of Post-Compulsory Education at the University of Worcester, specialising in education policy, leadership and lifelong learning. 